\title{
MONITORING KUALITAS AIR TEMPORAL DAN UJI LOGAM PADA KERANG KAPAH (Meretrix meretrix) DI PANTAI AMAL LAMA KOTA TARAKAN
}

\section{TEMPORARY MEASUREMENT OF WATER QUALITY AND METAL ON KAPAH CLAM (Meretrix meretrix) IN THE PANTAI AMAL LAMA OF TARAKAN}

\author{
Muhammad Adriansyah', Miftakhul Fayzun ${ }^{1}$, Novita Sari Ardillah ${ }^{1}$, Yohan Peri ${ }^{1}$, Diana \\ Maulianawati $^{1 *}$, Heni Irawati ${ }^{2}$ \\ ${ }^{1}$ Program Studi Akuakultur, Fakultas Perikanan dan Ilmu Kelautan, Universitas Borneo Tarakan \\ ${ }^{2}$ Program Studi Manajemen Sumberdaya Perairan, Fakultas Perikanan dan IImu Kelautan Universitas \\ Borneo Tarakan \\ *Corresponding author: diana_perikanan@borneo.ac.id
}

\begin{abstract}
ABSTRAK
Perairan pantai amal merupakan perairan terbuka yang mendapatkan pengaruh besar dari lingkungan sekitarnya. Penelitian dilakukan untuk mengetahui tingkat toksisitas perairan sungai Amal Lama dengan cara pengambilan sampel air dan biota yang diambil di Sungai Amal Lama Kota Tarakan. Pengujian kualitas air meliputi nitrit secara spektrofotometri, kadar amoniak secara fenat, sulfida total secara iodometri, serta analisis kandungan logam (Al, Mn, Zn, Fe dan Cu) dalam biota. Data yang di peroleh dianalisis secara deskriptif. Hasil penelitian menunjukkan bahwa kadar sulfida total, amoniak, dan nitrit dari sampel uji secara berurutan adalah $4 \mathrm{mg} / \mathrm{L}, 0,299 \mathrm{mg} / \mathrm{L}$, dan nitrit 0,065 mg/L. Hasil uji logam Al, Mn, Zn, Fe, dan $\mathrm{Cu}$ nilai yang diperoleh adalah 0,07; 0,4; 0,1; 0,1 dan 0,6 mg/kg. berdasarkan hasil ini, dapat disimpulkan bahwa perairan Sungai Pantai Amal Lama masih layak untuk kehidupan organisme.
\end{abstract}

Kata Kunci : Kualitas Air, Amal Lama, Logam, Kapah, Meretrix meretrix

\section{ABSTRACT}

Pantai Amal is open waters that have a great influence from the environment. These researches were conducted to determine the level of toxicity of Pantai Amal Lama River sampling the water and biota at Sungai Pantai Amal Lama of Tarakan. Water quality tests include the nitrite used spectrophotometry, ammonia level was tested by ammonia phenate, the total of sulphide was determined by iodometric method, and the analysis of the metal ( $\mathrm{Al}, \mathrm{Mn}, \mathrm{Zn}, \mathrm{Fe}$ and $\mathrm{Cu}$ ) in the biota were determined by KIT for metal. Data that has been obtained is analyzed descriptively. Results showed that the concentration of total of sulfide, ammonia, and nitrite were $4 \mathrm{mg} / \mathrm{L}, 0.299$ $\mathrm{mg} / \mathrm{L}$, and nitrite $0.065 \mathrm{mg} / \mathrm{L}$, respectively. Metal test results $\mathrm{Al}, \mathrm{Mn}, \mathrm{Zn}, \mathrm{Fe}$ and $\mathrm{Cu}$ values obtained are 0.07; 0.4; 0.1; 0.1 and $0.6 \mathrm{mg} / \mathrm{kg}$. hence, according to this result, it could be concluded that the Pantai Amal Lama River still appropriate for the living of organisms.

Keywords: Water Quality, Amal Lama, Metal, Kapah, Meretrix meretrix 


\section{PENDAHULUAN}

Kota Tarakan memiliki luas daratan \pm 25.080 Ha yang sebagai besar telah dimanfaatkan untuk berbagai jenis pemanfaatan. Lahan Kota Tarakan, apabila ditinjau dari pola guna lahan yang ada, dapat terlihat bahwa hutan belukar masih mendominasi tutupan lahan. Penggunaan lahan selanjutnya adalah digunakan untuk kegiatan usaha pertanian/perikanan, pemukiman penduduk, fasilitas umum dan sosial, kegiatan industri dan perdagangan, serta penggunaan lahan lainnya (Succery, 2009). Berkaitan dengan pemukiman penduduk, maka tidak terlepas juga dengan kebutuhan akan sarana dan prasarana air bersih.

Kehidupan makhluk hidup tergantung dari apa yang terjadi di lingkungannya. Lingkungan yang terbuka mudah dimasuki bahan-bahan yang tidak diketahui misalnya limbah yang mengandung bahan berbahaya dan beracun (B3). Lingkungan perairan adalah zona bebas yang mudah dimasuki effluent baik secara langsung melalui pipapipa pembuangan ataupun run off dari aliran bawah tanah.

Limbah-limbah industri yang banyak menggunakan bahan kimia dapat masuk ke badan sungai, termasuk limbah berupa bahan organik yang dihasilkan dari kegiatan akuakultur. Semua limbah yang dihasilkan tersebut, sebagian besar dapat menimbulkan efek toksik terhadap lingkungan perairan yang menjadi tempat akhir pembuangan limbah. Efek yang ada dapat mengakibatkan menurunnya kualitas suatu perairan atau menimbulkan pengaruh terhadap biota yang terpapar langsung dengan zat yang mengandung racun yang terlarut di perairan. Efek keracunan yang terjadi dapat bersifat akut, sub-akut, ataupun kronis. Hal ini ditentukan oleh frekuensi waktu maupun lama paparan, lokasi organ yang terpapar (lokal/sistemik), dan besarnya konsentrasi toksikan.
Bahan pencemar yang dapat mengotori perairan serta bersifat toksik dapat berupa senyawa kimia organic, anorganik atau mineral-mineral beracun. Senyawa ini dapat bersifat mematikan bagi organisme perairan. Sumber utama bahan pencemar pada umumnya berasal dari berbagai aktivitas industry, dari industry skala kecil hingga besar, kegiatan pertambangan, erosi permukaan tanah tambang, kegiatan pertanian yang menggunakan herbisida dan insektisida, serta tumpahan minyak yang disebabkan kecelakaan ataupun kebakaran kapal di laut (Burkholder \& Shumway, 2011). Khusus tentang limbah yang berasal dari kegiatan industri, pencemar yang dihasilkan sangat dipengaruhi oleh jenis industri misalnya industri penyamakan kulit yang menghasilkan limbah logam $\mathrm{Cr}^{6+}$ (Sugihartono, 2016), industri tekstil yang menghasilkan limbah berupa zat warna sintetik (Irawati et al., 2018), logam merkuri yang dihasilkan dari penambangan emas (Widodo, 2008), serta limbah yang berasal dari kegiatan pasar tradisional (Maulianawati et al., 2018).

Kerang kapah merupakan salah satu jenis bivalvia yang memiliki karakteristik yang sama dengan jenis bivalvia lainnya, kerang kapah pada umumnya memperoleh nutrient atau pakan dari lingkungannya (Hargreaves, 2011). Bivalvia juga dikelompokkan dalam filter feeder, yaitu kelompok hewan yang mengkonsumsi dan menyerap berbagai senyawa yang terdapat dalam lingkungannya terutama logam berat.

Perairan pantai amal merupakan wilayah yang umumnya dimanfaatkan sebagai tempat wisata, budidaya rumput laut, dan usaha pembenihan udang windu yang menggunakan air bersumber dari Pantai Amal Lama. Kerang kapah yang diperjualbelikan saat ini, sebagian diperoleh dari wilayah ini. Besarnya pemanfaatan wilayah Pantai Amal Lama, serta pentingnya informasi mengenai keamanan sumberdaya 
yang digunakan, baik sumber air maupun sumber protein hewani, maka perlu dilakukan pengamatan awal terkait status mutu kualitas air di wilayah tersebut serta kandungan logam yang terkonsentrasi pada kerang kapah.

\section{METODOLOGI}

\section{Waktu dan Tempat}

Penelitian dilaksanakan di perairan Sungai Amal Lama dan berlangsung pada bulan April sampai dengan Mei 2018. Pemeriksanaan kualitas air dan analisis kandungan logam dalam biota dilakukan di Laboratorium Lingkungan dan Laboratorium Kualitas Air Fakultas Perikanan dan Ilmu Kelautan Universitas Borneo Tarakan. Titik pengambilan sampel air dan biota dapat dilihat pada Gambar 1.

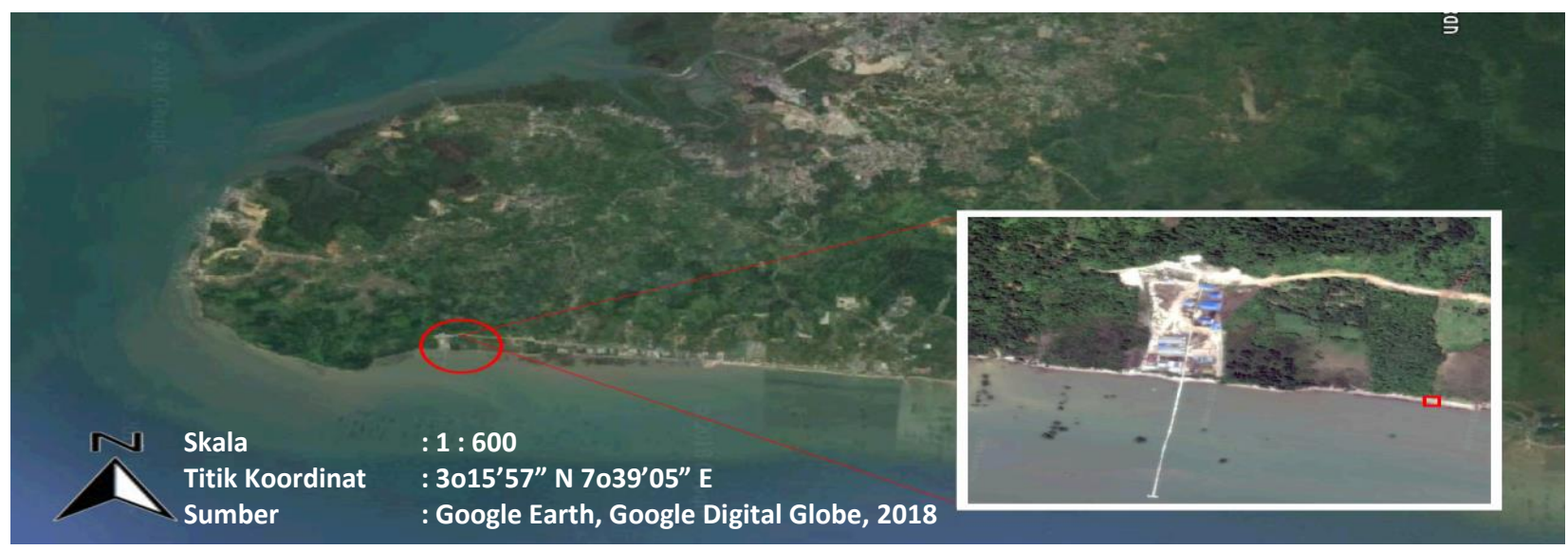

Gambar 1. Peta Lokasi Pengambilan Sampel

\section{Alat dan Bahan}

Bahan yang digunakan terdiri dari sampel air dan kerang kapah (M. meretrix). Bahan lainnya adalah pereaksi kimia untuk analisis kualitas air, dan analisis logam. Peralatan yang digunakan dalam penelitian ini antara lain: botol, kertas $\mathrm{pH}$, cooler box, botol sampel, syringe, mikro pipet, timbangan analitik, dan peralatan menulis. Untuk analisis logam $\mathrm{Cu}, \mathrm{Al}, \mathrm{Zn}, \mathrm{Fe}, \mathrm{Mn}$ yang terdapat dalam biota menggunakan labu ukur, pipet volumetrik, pipet ukur, gelas piala, labu erlenmayer, neraca analitik, dan spektrofotometer UV-Vis.

\section{Prosedur Penelitian}

Pengambilan Sampel Air, Biota, dan Pengawetan Sampel

Parameter suhu dan $\mathrm{pH}$ diukur secara insitu, sedangkan untuk parameter amoniak, nitrit, dan sulfida total dilakukan pengambilan sampel air secara langsung dengan botol PE berukuran $200 \mathrm{~mL}$ pada tepian sungai, sampel air yang diambil kemudian ditetesi beberapa bahan kimia atau pengawetan untuk analisis kualitas air. Untuk analisis sulfida air ditetesi Zn-Acetat $2 \mathrm{~N}$ sebanyak 4 tetes dan ditambahkan $\mathrm{NaOH}$ hinga $\mathrm{pH}>9$, untuk analisis amoniak sampel ditetesi $\mathrm{H}_{2} \mathrm{SO}_{4}$ sebanyak 2 tetes hingga $\mathrm{pH}>2$, kemudian sampel yang sudah diawetkan disimpan didalam cooler box. Sampel biota yang diambil berupa kerang kapah pada tepian sungai, selanjutnya dimasukkan ke dalam kantong plastik dan disimpan di dalam cooler box.

\section{Analisis Laboratorium}

Sampel air diuji kandungan nitrit menggunakan SNI-06-6989.9-2004 tentang Cara Uji Nitrit Secara Spektrofotometri. Amoniak menggunakan panduan SNI 06- 
6989.30-2005 bagian 30 tentang cara uji kadar amoniak dengan spektrofotometer secara fenat dan Pengujian Sulfida menggunakan panduan SNI 6989.75:2009 bagian 75 tentang cara uji sulfida secara iodometri.

\section{a. Analisis Kualitas Air}

Pada analisis kualitas air, parameter yang diamati adalah uji nitrit $\left(\mathrm{NO}_{2}\right)$, uji kadar amonia $\left(\mathrm{NH}_{3}\right)$ dengan metode spektrofotometri, dan sulfida dengan metode iodometri sesuai dengan standar SNI yang berlaku untuk pengujian sampel air.

\section{b. Analisis Kandungan Logam dalam Biota}

Sampel biota diambil dari tepian sungai dibersihkan dan dipisahkan antara daging dengan cangkangnya. Kemudian sampel didestruksi menggunakan larutan asam nitrat $\left(\mathrm{HNO}_{3}\right)$ selama 24 jam, setelah 24 jam sampel dilarutkan dalam aquades $(50 \mathrm{~mL})$ dan dianalisis kandungan logam $\mathrm{Cu}, \mathrm{Al}, \mathrm{Zn}, \mathrm{Fe}$ dan Mn dengan menggunakan metode testkit. Perhitungan kandungan logam dalam biota dapat dihitung dengan rumus sebagai berikut:

Konsentrasi Logam $=\mathrm{KS} \times \mathrm{VF} \times \frac{F P}{W F}$
Keterangan :
$\mathrm{KS} \quad=$ Konsentrasi Sampel
$\mathrm{VF} \quad=$ Volume Sampel
$\mathrm{WF} \quad=$ Berat Sampel
$\mathrm{FP} \quad=$ Faktor pengenceran

\section{HASIL DAN PEMBAHASAN}

Perairan laut merupakan suatu wilayah yang sangat dipengaruhi oleh berbagai aktivitas yang terjadi di wilayah daratan. Berbagai limbah yang bersumber dari kegiatan masyarakat akan sangat berdampak pada perairan laut yang pada umumnya dapat menyebabkan pencemaran air. Namun, laut juga merupakan tempat hidup utama biota perairan. Habitat yang baik bagi biota laut serta aktivitasnya salah satunya dipengaruhi oleh kualitas air.

Perolehan hasil pengukuran kualitas air secara insitu untuk parameter suhu sebesar $28{ }^{\circ} \mathrm{C}$ dan pH 8 (Tabel 1). Menurut Peraturan Pemerintah No. 82 Tahun 2001 tentang Pengelolaan Kualitas Air dan Pengendalian Pencemaran kisaran maksimum suhu sebesar 26-30 ${ }^{\circ} \mathrm{C}$ dan $\mathrm{pH}$ optimum antara $6-7$. Berdasarkan standar baku mutu yang berlaku dapat diketahui bahwa kisaran suhu dan $\mathrm{pH}$ dari pengukuran masih tergolong baik dan masih terjaga kualitasnya.

Tabel 1. Hasil Pengukuran Kualitas Air

\begin{tabular}{cccc}
\hline Parameter & Nilai & Baku Mutu* & Baku Mutu** \\
\hline Suhu $\left({ }^{\circ} \mathrm{C}\right)$ & 28 & - & $28-32$ \\
$\mathrm{pH}$ & 8 & $6-9$ & $7,5-8,5$ \\
Amoniak $(\mathrm{mg} / \mathrm{L})$ & 0,299 & 0,5 & $<0,01$ \\
Nitrit $(\mathrm{mg} / \mathrm{L})$ & 0,065 & 0,06 & $<0,01$ \\
Sulfida Total $(\mathrm{mg} / \mathrm{L})$ & 4 & - & - \\
\hline
\end{tabular}

*baku mutu berdasarkan PP No. 82 Tahun 2001

** baku mutu berdasarkan Permen KKP No. 75 Tahun 2016

Tinggi rendahnya suhu air perairan dapat dipengaruhi oleh intensitas sinar matahari dan vegetasi yang terdapat di sekitarnya. Hal ini juga terkait dengan lokasi pengambilan sampel air di tempat yang terbuka dan sangat dekat dengan pantai sehingga dapat dipengaruhi oleh sinar matahari langsung. Pemukiman warga sekitar Sungai Amal Lama masih tergolong sedikit dan masih terdapat berbagai vegetasi di sekitar perairan sungai, 
sehingga cukup untuk menstabilkan suhu di permukaan perairan dan sekitarnya. Marlina et al. (2017) menyatakan bahwa tinggi rendahnya suhu air dipengaruhi oleh intensitas sinar matahari dan kerapatan vegetasi di sekitar sungai. Banyaknya vegetasi dapat berfungsi sebagai stabilisator suhu dan kelembaban, pemasok oksigen $\left(\mathrm{O}_{2}\right)$ dan penyerap gas karbondioksida $\left(\mathrm{CO}_{2}\right)$.

\section{AMONIAK}

Kondisi $\mathrm{pH}$ akan berpengaruh pada kandungan amoniak dalam perairan sungai. Semakin tinggi $\mathrm{pH}$, maka kandungan amoniak $\left(\mathrm{NH}_{3}\right)$ juga akan semakin meningkat. Menurut Komarawidjaja (2006), amoniak yang tidak terionisasi lebih bersifat toksik daripada amoniak dalam bentuk ion, sedangkan sifat toksik amoniak akan semakin meningkat ketika $\mathrm{pH}$ perairan mencapai lebih dari 9.

Amoniak merupakan senyawa nitrogen anorganik di lingkungan perairan yang dapat teroksidasi menjadi nitrit. Hasil pengujian sampel air yang dilakukan diperoleh kadar amoniak sebesar 0,299 mg/L (Tabel 1). Berdasarkan baku mutu air PP No.82 Tahun 2001 tentang Pengelolaan Kualitas Air dan Pengendalian Pencemaran maksimum yang diperbolehkan adalah sebesar 0,5 mg/L. Jadi dapat diketahui bahwa kadar amoniak dari sampel air yang diukur masih tergolong baik.

Rendahnya kadar amoniak dalam badan perairan Sungai Amal Lama dikarenakan kondisi di sekitar sungai yang masih jarang penduduk dan jauh dari perindustrian, sehingga belum terlalu banyak aktifitas manusia di sepanjang bantaran sungai. Menurut Putri et al. (2019), sumber nitrogen di perairan dapat berasal dari air seni dan tinja, oksidasi bahan organik oleh mikroba, air buangan industri serta berbagai aktifitas manusia seperti pada bidang pertanian, perikanan, kehutanan dan sebagainya.

\section{NITRIT}

Hasil uji nitrit secara spektrofotometri pada Tabel 1 dapat diketahui bahwa nilai konsentrasi nitrit pada sampel yang diambil pada daerah aliran sungai sekitar pantai Amal Lama Kota Tarakan sebesar 0,065 mg/L. Kisaran maksimum nitrit yang diperbolehkan menurut Peraturan Pemerintah No. 82 Tahun 2001 tentang Pengelolaan Kualitas Air dan Pengendalian Pencemaran adalah 0,06 mg/L. Kadar nitrit di perairan Sungai Amal Lama masih tergolong baik meskipun sedikit lebih tinggi dibandingkan baku mutu air yang dipersyaratkan. Hal ini terkait kandungan nitrogen yang terdapat dalam perairan. Menurut Maulianawati et al. (2018), kandungan nitrit yang tinggi dalam badan air sungai dapat disebabkan oleh pembuangan sampah di sekitar sungai. Hal ini mengingat bahwa Sungai Amal Lama sangat dekat dengan daerah pariwisata Pantai Amal Lama, sehingga menyebabkan tingginya kadar nitrogen dalam air sungai.

Nitrogen dalam perairan sungai dapat berupa nitrogen organik maupun anorganik. Nitrogen sendiri merupakan kebutuhan pokok bagi organisme karena unsur nitrogen diperlukan dalam proses sintesis protein (nitrogen organik). Sedangkan nitrit adalah salah satu dari bentuk nitrogen anorganik yang terdapat dalam perairan. Nitrit di perairan merupakan hasil oksidasi biokimia dari amoniak atau reduksi nitrat. Keberadaan nitrit sangat berpengaruh pada ketersediaan oksigen dalam air. Aswadi (2006) menyatakan bahwa dalam proses nitrifikasi diperlukan sejumlah oksigen agar terjadi oksidasi senyawa amoniak menjadi nitrit dan oksidasi nitrit menjadi nitrat. Namun bila dalam keadaan anaerob, reaksi nitrifikasi tidak dapat berlangsung, sehingga reduksi nitrat dapat meningkat dalam kondisi oksigen terlarut yang rendah ( 0 $-2 \mathrm{mg} / \mathrm{L})$. 


\section{Uji Sulfida Total}

Belerang atau sulfur dalam perairan sebagai sulfida $\left(\mathrm{H}_{2} \mathrm{~S}\right)$ yang merupakan gas hasil dekomposisi senyawa organik oleh bakteri anaerob. Sulfida sebagai salah satu gas yang berbahaya bagi biota di perairan, juga menghasilkan bau yang menyengat. Pada hasil uji sulfida secara iodometri dari sampel yang diambil dapat diketahui bahwa nilai sulfida total hasil pengukuran pada sampel permukaan diperoleh hasil sebesar $4 \mathrm{mg} / \mathrm{L}$. Menurut Peraturan Menteri Lingkungan Hidup No.5 Tahun 2014 tentang Baku Mutu Air Limbah bahwa kisaran maksimum untuk kandungan sulfida di perairan adalah sebesar $1 \mathrm{mg} / \mathrm{L}$. Tingginya kandungan sulfida total dalam sampel yang diambil di daerah aliran sungai sekitar pantai amal lama Kota Tarakan dikarenakan aliran sungai berdekatan dengan kawasan wisata Pantai Amal Lama sehingga dimungkinkan adanya limbah organik dari aktivitas manusia di kawasan tersebut. Permana dan Widyastuti (2013) menyatakan bahwa meningkatnya nilai sulfida total di perairan dapat disebabkan oleh pupuk organik, timbunan sampah dan sisa-sisa tumbuhan yang telah membusuk dalam badan air sungai.

\section{Analisis Kandungan Logam pada Biota}

Perairan Pantai Amal Lama merupakan salah satu situs pariwisata yang ada di Kota Tarakan. Perairan di pantai ini juga dimanfaatkan sebagai tempat budidaya rumput laut dan usaha pembenihan udang windu yang menggunakan air bersumber dari Pantai Amal Lama. Untuk mengetahui kualitas perairan sekitar wilayah Amal Lama, tidak cukup hanya mengetahui parameter suhu, $\mathrm{pH}$, amoniak dan nitrit yang ada di perairan sungainya saja. Kualitas perairan juga dapat diketahui dari kandungan logam yang terdapat pada bivalvia yang hidup di sekitar perairan Amal Lama seperti kerang kapah (M. meretrix). Kerang kapah (M. meretrix) merupakan komoditi hewani yang menjadi ikon kuliner di sepanjang Pantai
Amal Lama. Oleh karena itu dilakukan pengujian kandungan logam dalam kerang kapah (M. meretrix) seperti yang ditampilkan dalam Tabel 2.

Tabel 2. Hasil uji Kandungan Logam

\begin{tabular}{cc}
\hline Jenis logam & Konsentrasi (mg/kg) \\
\hline $\mathrm{Cu}$ & 0,60 \\
$\mathrm{Al}$ & 0,07 \\
$\mathrm{Zn}$ & 0,10 \\
$\mathrm{Fe}$ & 0,10 \\
$\mathrm{Mn}$ & 0,40 \\
\hline
\end{tabular}

Kerang kapah (M. meretrix) dapat dijadikan sebagai salah satu bioindikator pencemaran lingkungan. Hasil pengujian kandungan logam dari sampel kerang kapah $(M$. meretrix) yang diambil pada lokasi pengambilan sampel di daerah aliran sungai pantai Amal Lama Kota Tarakan di dapat hasil pengujian logam $\mathrm{Cu}$ dengan konsentrasi sebesar 0,6 mg/kg. Menurut Surat Keputusan Direktoral Jenderal Pengawasan Obat dan Makanan, Departemen Kesehatan Republik Indonesia Nomor: 03725/B/SK/1989, batas maksimum kadar logam $\mathrm{Cu}$ yang diperbolehkan yaitu sebesar $20 \mathrm{mg} / \mathrm{kg}$, yang artinya kandungan logam $\mathrm{Cu}$ dalam kerang kapah (M. meretrix) masih berada di bawah ambang batas maksimum yang diperbolehkan.

Logam berat tembaga $(\mathrm{Cu})$ di perairan menurut Cahyani et al. (2012) dapat berasal dari limbah domestik maupun industri. Tembaga $(\mathrm{Cu})$ dapat mengendap pada sedimen perairan hingga masuk ke dalam organisme. Logam ini bersifat mudah mengikat senyawa organik dan secara bersama-sama mengendap pada sedimen, sehingga dengan mudah diabsorpsi oleh makrobentos seperti kerang kapah (M. meretrix). Namun wilayah Amal Lama masih jauh dari aktivitas industri dan pemukiman yang padat sehingga kandungan logam $\mathrm{Cu}$ pada kerang kapah (M. meretrix) tergolong rendah. 
Baku mutu seng (Zn) menurut Permen. LH No. 51 Tahun 2004 adalah 0,05 mg/kg, sedangkan hasil analisis yang diperoleh sebesar $0,10 \mathrm{mg} / \mathrm{kg}$. Menurut Suyanto et al. (2010), kandungan Zn yang cukup tinggi pada bivalvia dikarenakan logam $\mathrm{Zn}$ merupakan logam esensial yang dibutuhkan organisme untuk pengaturan metabolisme.

Sebagaimana logam Zn, besi (Fe) juga merupakan logam esensial yang dibutuhkan dalam proses metabolisme dan dapat terakumulasi dalam jaringan organisme dengan jumlah tertentu. Logam besi akan menjadi toksik bagi organisme jika jumlahnya sangat berlebihan. Besi $(\mathrm{Fe})$ yang ditemukan dalam kerang kapah (M. meretrix) sebesar $0,10 \mathrm{mg} / \mathrm{kg}$. Selain besi (Fe), mangan (Mn) merupakan salah satu logam yang banyak ditemukan dalam badan perairan.

Kadar Mn dari hasil pengujian pada kerang kapah (M. meretrix) yang diperoleh sebesar $0,4 \mathrm{mg} / \mathrm{kg}$. Kadar tersebut masih berada di bawah standar maksimum yang ditetapkan dalam peraturan FAO (2014) dengan strandar konsentrasi dalam hewan laut sebesar 0,6 $\mathrm{mg} / \mathrm{kg}$. Menurut Aisyah et al. (2017) mangan dapat berasal dari sumber alami maupun xenobiotik. Sumber alami mangan dapat berasal dari tanah dan batuan penyusunnya. Namun tinggi rendahnya kadar mangan bergantung pada kandungan oksigen terlarut dalam air sehingga membentuk oksida yang menyebabkan logam mangan semakin terendap di dasar perairan dan terakumulasi dalam kerang kapah (M. meretrix).

Logam selanjutnya dalam penelitian ini adalah aluminium (Al). Kadar logam $\mathrm{Al}$ dalam kerang kapah (M. meretrix) diperoleh sebesar $0,07 \mathrm{mg} / \mathrm{kg}$. Supriyantini dan Endrawati (2015) menyatakan bahwa sebagian besar logam seperti $\mathrm{Al}, \mathrm{Fe}, \mathrm{Cu}, \mathrm{Pb}$, serta $\mathrm{Zn}$ mudah terlarut dan sangat mobile pada $\mathrm{pH}$ di bawah 5. Sedangkan pada $\mathrm{pH}$ rendah, logam-logam seperti $\mathrm{Al}, \mathrm{Fe}$ dan $\mathrm{Mn}$ akan bersifat toksik.

\section{KESIMPULAN}

Kualitas air Sungai Amal Lama Kota Tarakan masih tergolong baik dan sesuai dengan baku mutu air untuk parameter fisika dan kimia seperti: suhu, $\mathrm{pH}$, nitrit, amoniak, dan sulfida. Selain itu kandungan logam berat pada biota uji yakni kerang kapah (M. meretrix) masih di bawah ambang batas yang diperbolehkan sesuai peraturan.

\section{DAFTAR PUSTAKA}

Aisyah, A.N., Utomo, K.P., dan Jati, D.R. 2017. Analisis dan Identifikasi Status Mutu Air Tanah Di Kota Singkawang Studi Kasus Kecamatan Singkawang Utara. Jurnal Teknologi Lingkungan Lahan Basah. 5(1): 110.

Aswadi, M. 2006. Pemodelan Fluktuasi Nitrogen (Nitrit) pada Aliran Sungai Palu. Jurnal Smartek. 4(2): 112125.

Batu, D.F.L. 2017. Ekotoksikologi Perairan. Bogor: IPB Press.

Badan Standarisasi Nasional [BSN]. 2006. Standar Nasional Indonesia 01-2729. Uji Organoleptik Ikan Segar. Jakarta: Badan Standarisasi Nasional Indonesia.

Cahyani, M.D., Azizah, R., dan Yulianto, B. 2012. Studi Kandungan Logam Berat Tembaga $(\mathrm{Cu})$ pada Air, Sedimen, dan Kerang Darah (Anadara granosa) di Perairan Sungai Sayung dan Sungai Gonjol, Kecamatan Sayung, Kabupaten Demak. Journal of Marine Research. 1(2): 73-79. 
Dix, H.M. 1981. Environment Pollution. United States: John Wiley \& Sons Ltd.

Irawati, H., Aprilita, N.H., dan Sugiharto, E. 2018. Adsorpsi Zat Warna Kristal Violet Menggunakan Limbah Kulit Singkong (Manihot esculenta). BIMIPA. 25(1): 17-31.

Komarawidjaja, W. (2006). Pengaruh Perbedaan Dosis Oksigen Terlarut (DO) pada Degradasi Amonium Kolam Kajian Budidaya Udang. Jurnal Hidrosfir. 1(1): 32-37.

Marlina, N., Hudori dan Hafidh, R. (2017). Pengaruh Kekasaran Saluran dan Suhu Air Sungai pada Parameter Kualitas Air COD, TSS Di Sungai Winongo Menggunakan Software QUAL2Kw. Jurnal Sains dan Teknologi Lingkungan. 9(2):122133.

Maulianawati, D., Herman, M.I., Ismail, M., Fiandaka, M.O.A., Sadrianto, Tarfin, dan Irawati, H. 2018. Asesmen Kualitas Air Permukaan Di Sungai Pamusian Kota Tarakan. Jurnal Harpodon Borneo. 11(2): 97-103.

Pemerintah Republik Indonesia, 2001. Peraturan Pemerintah Nomor 82 Tahun 2001 tentang Pengelolaan Kualitas Air dan Pengendalian Pencemaran Air. Jakarta, Sekretariat Negara.

Permana, D.I. dan Widyastuti, M. 2013. Studi Perubahan Kualitas Air Sungai Winongo Tahun 2003 dan 2012. Jurnal Bumi Indonesia. 2(2): 53-62.

Putri, W.A.E., Purwiyanto, A.I.S., Fauziyah, Agustriani, F., dan Suteja, Y. (2019). Condition of Nitrate, Nitrite,
Ammonia, Phosphate, and BOD of Banyuasin River Estuary, South Sumatera. Jurnal Ilmu Teknologi dan Kelautan Tropis. 11(1): 65-74.

SNI 06-6989.30-2005. Bagian 30 Tentang Cara uji kadaramonia dengan spektro fotometer secara fenat.

SNI 6989.75: 2009. Bagian 75 tentang Cara uji sulfida secara iodometri.

SNI-06-6989.9-2004 tentang Cara Uji Nitrit Secara Spektrofotometri.

Southwick, C.H. 1976. Ecology and the Quality of Our Environment. Second Edition. D. Van Nostrand Company, New York.

Succery. 2009. Monografi profil Kabupaten/Kota. http://sucessary. wordpress.com/2009/04/03/monogr afi-profil-kabupaten-kota/.

Sugihartono. 2016. Pemisahan Krom pada Limbah Cair Industri Penyamakan Kulit Menggunakan Gelatin dan Flokulan Anorganik. Majalah Kulit Karet dan Plastik. 32(1): 21-30.

Supriyantini, E. dan Endrawati, H. 2015. Kandungan Logam Berat Besi (Fe) pada Air, Sedimen, dan Kerang Hijau (Perna viridis) Di Perairan Tanjung Emas Semarang. Jurnal Kelautan Tropis. 18(1): 38-45.

Suyanto, A., Kusmiyati, S., dan Retnaningsih, C. 2010. Residu Logam Berat Ikan Dari Perairan Tercemar Di Pantai Utara Jawa Tengah. Jurnal Pangan dan Gizi. 01(02): 33-38.

Widodo. 2008. Pengaruh Perlakuan Amalgamasi Terhadap Tingkat Perolehan Emas dan Kehilangan 
Merkuri. Jurnal Riset Geologi dan

Pertambangan. 18(1): 47-53. 